\title{
パルスレーザーでコントロールする銀ナノプレートの抗菌活性
}

市丸 裕晃 ${ }^{1}$, Kaung KYAW ${ }^{1}$, 川越 嵩之 ${ }^{1}$, 寺川 光洋 ${ }^{2}$, 宮澤 雄太 ${ }^{3}$,

溝口 大剛 ${ }^{3}$, 津志田 雅之 ${ }^{4}$, 新留 㻟郎 ${ }^{1}$

1熊本大学大学院 先端科学研究部 (广860-8555 熊本市中央区黒髪2-39-1)

慶應義塾大学 理工学部 ( ₹223-8522 神奈川県横浜市港北区日吉3-14-1)

${ }^{3}$ 大日本塗料株式会社（３24-8516 栃木県大田原市下石上1382-12）

4熊本大学工学部 (

\section{Antibacterial Activities of Silver Nanoplates Controlled by Pulsed Laser}

\author{
Hiroaki ICHIMARU, ${ }^{1}$ Kaung KYAW, ${ }^{1}$ Takayuki KAWAGOE, ${ }^{1}$ Mitsuhiro TERAKAWA, ${ }^{2}$ Yuta MIYAZAWA, ${ }^{3}$ \\ Daigou MIZOGUCHI, ${ }^{3}$ Masayuki TSUSHIDA, ${ }^{4}$ and Takuro NIIDOME ${ }^{1}$ \\ ${ }^{1}$ Faculty of Advanced Science and Technology, Kumamoto University, 2-39-1 Kurokami, Chuo-ku, Kumamoto 860-8555 \\ ${ }^{2}$ Department of Electronics and Electrical Engineering, Keio University, 3-14-1 Hiyoshi, Kohoku-ku, Yokohama 223-8522 \\ ${ }^{3}$ Dai Nippon Toryo Co., Ltd. 1382-12 Shimoishigami, Otawara, Tochigi 324-8516 \\ ${ }^{4}$ Technical Division, Faculty of Engineering, Kumamoto University, 2-39-1 Kurokami, Chuo-ku, Kumamoto 860-8555
}

(Received June 15, 2017)

\begin{abstract}
Silver nanoplates coated with gold, when subjected to pulsed laser irradiation, changed their shape from triangular to spherical structure along with the shift of their extinction spectra. Simple crystal structure of the silver nanoplates changed to multiple small crystal domains. The ratio of silver to gold on the surface also changed from 22:1 to 4.5:1 enabling more silver to be released. As a result, the antibacterial activity of gold-coated silver nanoplates was significantly increased after pulsed laser irradiation.
\end{abstract}

Key Words: Pulsed laser, Silver nanoplate, Antibacterial activity, Gold coating

\section{1. 緒 言}

金属ナノ粒子はバルク材料では見られない独特の性質 を持つことから，様々な産業での応用が期待されてい る1,2). 特に，金ナノ粒子は大きさ，形状を変えること で光学特性が変化することが知られており, バイオイ メージングや診断薬，治療などの医療材料として応用さ れている3,4)，その中でも，金ナノロッドは，光を熱に 変換するフォトサーマル効果を有して扔り, 新しい医療 材料として期待されている. 以前, 我々は金ナノロッド 溶液に近赤外域の連続波レーザーを照射すると温度上昇 が起こるが，パルスレーザー照射では溶液の温度上昇が 起こらないことを見出した5,50).これは，パルスレー ザーによりロッド状の形状が球状に変化し, するともは や近赤外域に吸収をもたず，さらなる発熱が起こらない ためである、溶液全体の温度上昇は起こさずに, 瞬間的 かつ局所的な発熱とナノ粒子の形状変化を起こすこの現 象は, 薬物放出を量的, 空間的, 時間的にコントロール するドラッグデリバリーシステム (DDS)のデバイスとし て期待されている.

銀ナノ粒子は抗菌剂として機能することが古くから知
られている ${ }^{7.8)}$. 銀ナノ粒子から放出される銀イオンが 細菌のタンパク質等に結合し，その増殖を抑え，様々な 菌に対して，効果的な抗菌活性を示す。しかし，極まれ に銀に耐性を持った細菌も報告されている9 ．粒子から の銀イオンの放出量や放出速度はその粒子の作り方に よって異なっており，粒子の表面構造が関係していると 言われている ${ }^{10)}$. これまで衛生用品として実用化されて いる銀ナノ粒子であるが，感染症治療のための抗菌郕と しての応用は進んでいない，その理由の一つとして，銀 ナノ粒子は体内で凝集しやすく，その結果，抗菌活性が すぐに低下してしまうことが挙げられる。

我々はこれまで三角形プレート状の銀ナノ粒子を金で コートし，分散安定性を高めることに成功している(未 発表デー夕)。分散安定性を高める以外にも，金表面は チオール基を介し，ポリマーや核酸，タンパク質など 様々な機能性修飾ができる，金原子が平均2層となるよ うにコートした場合, 分散安定性を保ちつつ, 高い抗菌 活性を示したが，4層コートした場合，抗菌活性が大き く低下し，これは金層が厚すぎて，銀イオンが放出され なくなっているからと考えられる。

銀ナノプレートは異方性のナノ粒子である，前述の金 
ナノロッドのようにパルスレーザーを照射すると, 球状 に変形することが期待される，また，抗菌活性を示さな い金4層コート銀ナノプレートにパルスレーザーを照射 すれば, 変形の過程で内部の銀が表面に現れ，銀イオン が放出されれば，抗菌活性が表れるのではないかと着想 した。 これは抗菌活性を光照射でコントロールするシス テムとなる，そこで本研究ではこの金コート銀ナノ粒子 へのパルスレーザー照射による形状変化と抗菌活性の変 化について調べた。

\section{2. 金コート銀ナノプレートのパルスレーザー照射 による形状変化}

銀ナノ粒子およびその金コートはAherneら, あるい は, Gaoらの方法にしたがって作製した ${ }^{11,12)}$. その金 コート銀ナノ粒子を細胞培養用の 24 穴プレートに入れ, パルスレーザー(Q-switched Nd:YAG laser, $532 \mathrm{~nm}, 6 \mathrm{ns,}$ $10 \mathrm{~Hz}, 25 \mathrm{~mJ} / \mathrm{pulse}$, ビーム径 $6 \mathrm{~mm}$ ) で1分間照射した。 その結果, 青色だった金コート銀ナノ粒子が黄色に変化 L (Fig. 1, inset), 分光光度計を用いて, 消失スペクトル を測定した結果，パルスレーザー照射前の630 nmの ピークが低下し，新たに，450 nmのピークが現れた (Fig. 1).このことから, 大きな形状変化が起こったこ とがわかり，実際に透過型電子顕微鏡 (JEOL, JEM1400 Plus) で観察してみると, 三角形のナノプレートが 球状へ変化したことが確かめられた(Fig. 2). パルス レーザー照射前後のTEM画像から各形状の割合を算出 した結果，レーザー照射前では三角プレート状の粒子の 割合は48\%であったが, 照射後では6\%まで減少した(標 本数：照射前 138 個, 照射後 125 個).

\section{3. パルスレーザー照射による硝酸耐性の変化}

パルスレーザー照射による変形後, 表面の金層がどの ようになっているかを調べるために，粒子の硝酸耐性を 評価した４原子層の金コートが維持されていれば硝酸 耐性に変化はなく，金と銀が合金となって，銀が表面に 存在すれば，耐性が減少しているはずである。パルス

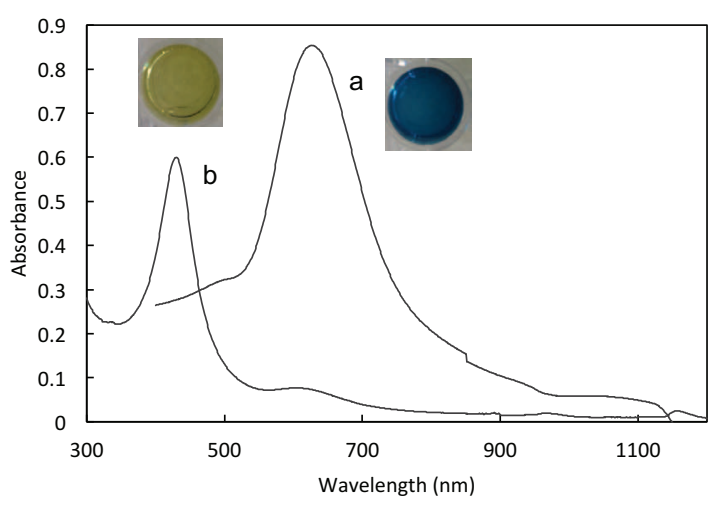

Fig. 1 Extinction spectrum of gold-coated silver nanoplates (a) before and (b) after pulsed laser irradiation. The inset shows color change (a) before and (b) after pulsed laser irradiation.
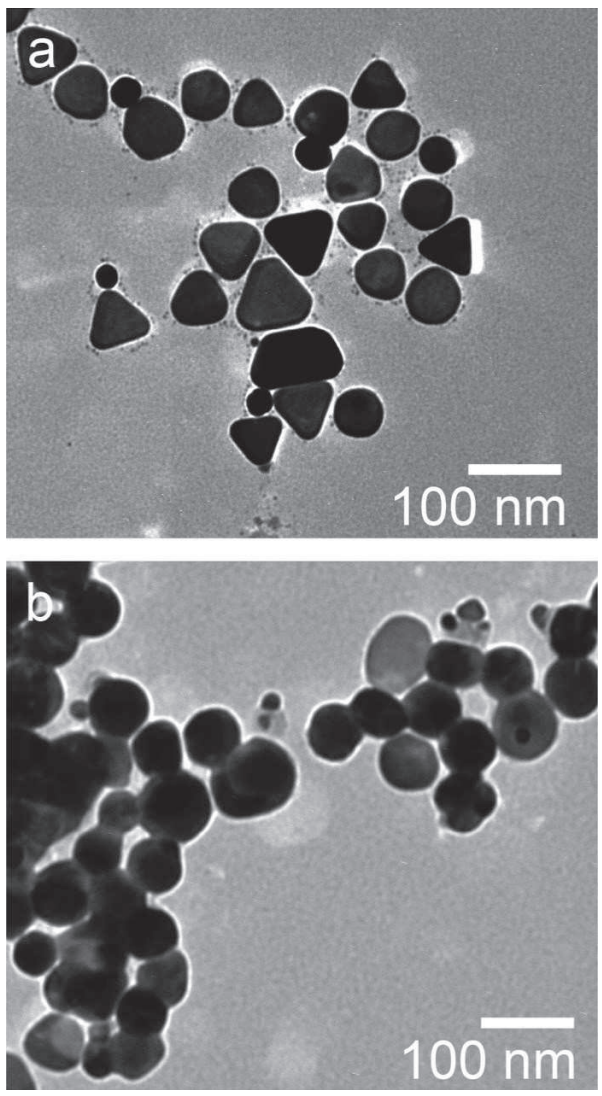

Fig. 2 Shape changes of gold-coated silver nanoplates shown by TEM images of (a) before and (b) after pulsed laser irradiation.

レーザー照射前後のサンプル $100 \mu \mathrm{L} に 2 \mathrm{mM}, 5 \mathrm{~m} \mathrm{M}$, $10 \mathrm{mM}, 20 \mathrm{mM}, 50 \mathrm{mM}$ 硝酸 $900 \mu \mathrm{L}$ 混合し, 室温 で30分間静置し, 分光光度計で吸収スペクトルを測定した (Fig. 3). その結果，パルスレーザー照射前後において， ほぼ同じような耐性を示した。金コート銀ナノプレートのコア シェル構造を保ったまま球状へ変化したものと考えられる.

\section{4. パルスレーザー照射による銀/金比の変化}

金コート銀ナノ粒子のパルスレーザー照射前後におけ る粒子の銀と金の量比をエネルギー分散型X線分析 (EDX; FEI TECNAI F20)で解析した。 その結果，照射前 は銀と金の比が22:1であったのが，照射後は4.5:1になっ ていた，金に対して，銀が減少していることから，パル スレーザー照射による変形で，一部の銀が粒子から放出 されていることが示された。

\section{5. パルスレーザー照射による抗菌活性の変化}

レーザー照射前後の金コート銀ナノプレートの大腸菌 (DH-5 $\alpha$ )に対する抗菌活性をコロニーカウント法を用い 評価を行った(Fig. 4)。まず, 試料中の分散安定剤を取り 除くため, 遠心分離機で遠心し $\left(12,000 \mathrm{~g}, 10 \mathrm{~min}, 4^{\circ} \mathrm{C}\right)$, 上清を取り除いた後, 超純水に再分散させた。一方 で, $37^{\circ} \mathrm{C}$ で16 時間培養した大腸菌を 10,000 倍希釈した ものを大腸菌液として抗菌活性試験に用いた。この大腸 

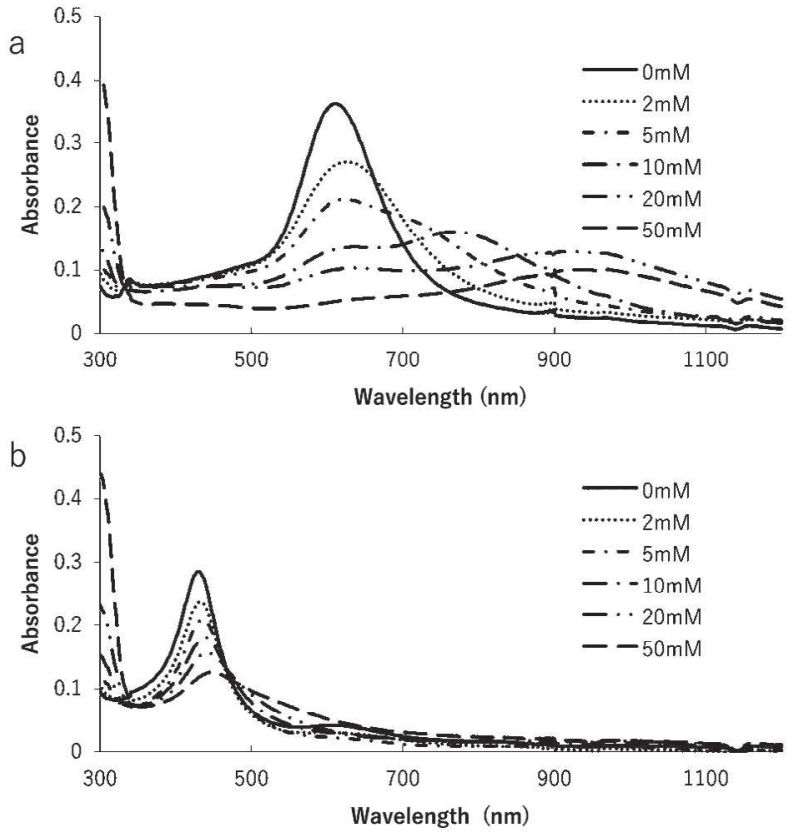

Fig. 3 Spectrum change of gold-coated silver nanoplates (a) before and (b) after pulsed laser irradiation after addition of several concentration of nitric acid.

菌液200 $\mu \mathrm{L}$ とサンプルを $50 \mu \mathrm{L}$ を 96 穴マイクロプレート 上で混合し， $37^{\circ} \mathrm{C} て ゙ 16$ 時間培養した。 その後，その中 に含まれている大腸菌数をカウントするために, リン酸 緩衝生理食塩水 $(\mathrm{PBS})$ で $10^{3}, 10^{4}, 10^{5}$ 倍に希釈し，寒天

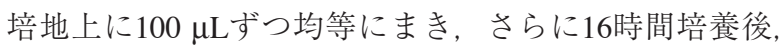
寒天培地上に生成したコロニー数をカウントし, 大腸菌 数とした，そして，それぞれのサンプルの大腸菌に対す る抗菌活性を評価した。

その結果，パルスレーザー照射前の粒子では $40 \%$ 程度 の大腸菌の減少が認められたが, パルスレーザー照射後 ではすべての大腸菌が死滅していた。

\section{6. ナノ粒子からの銀イオン放出評価}

レーザー照射前後の金コート銀ナノプレートからの銀 イオンの放出をイオンを誘導結合プラズマ発光分光分析 法(Inductively Coupled Plasma Optical Emission Spectrometry：ICP-OES)で定量した。その結果，パルスレーザー 照射前の金コート銀ナノプレートからの銀イオン放出量 は0.035 ppmであったのに対し，パルスレーザー照射後 の銀イオン放出量は $0.2 \mathrm{ppm}$ と打よそ6倍增加した (Fig. 5)。硝酸耐性試験の結果と合わせると，金コート 銀ナノプレートにパルスレーザーを照射すると，金コー 卜の拉よその厚さは変わらないが，その過程で，一部の 銀が粒子外に放出され，それが抗菌活性を示したもので はないかと考えている。

\section{7. 結 語}

本研究では，金コート銀ナノプレートにパルスレー ザー照射すれば，球状に変形し，同時に銀イオンが放出

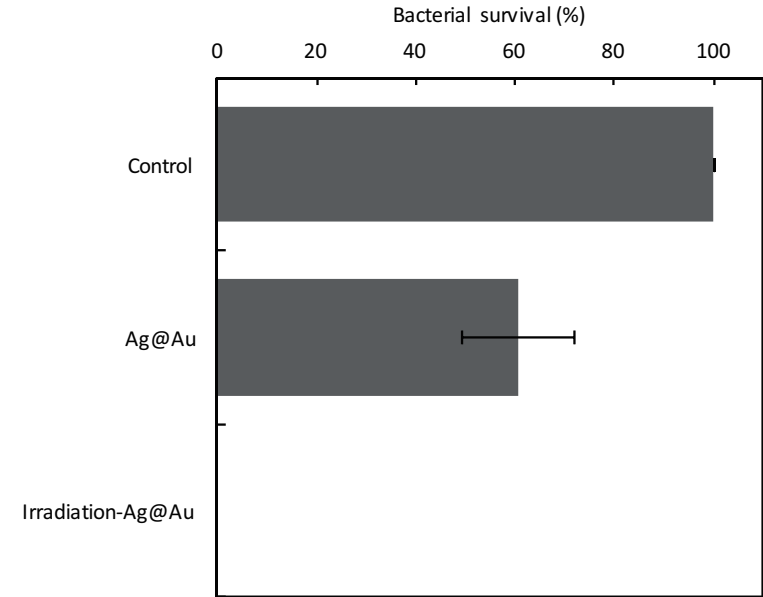

Fig. 4 Antibacterial activity of gold-coated silver nanoplates with or without pulsed laser irradiation.

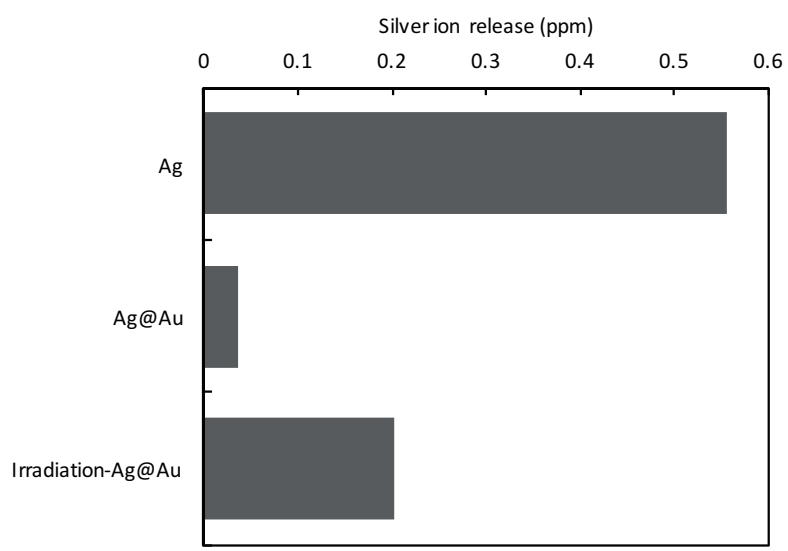

Fig. 5 Comparison of silver ion release of gold-coated silver nanoplates before and after pulsed laser irradiation.

されることを明らかにした。この銀イオンが抗菌活性を 示し，これは光で活性をコントロールできる抗菌剤と言 える。このシステムが実際にどのように応用できるかは わからないが，少なくとも銀の抗菌活性を理解するため のツールにはなると期待している。 今後はパルスレー ザーの照射条件と形状変化, 物性変化, そして, 抗菌活 性, 抗力ビ活性, 細胞傷害性変化など多面的な評価を進 めていきたい.

謝 辞

本研究は独立行政法人国際協力機構 (JICA)および熊 本大学拠点研究Bのサポートの下で行われた.

\section{参考文献}

1) V. Mody, R. Siwale, A. Singh, and H. Mody: J. Pharm. Bioal. Sci. 2 (2010) 282

2) J. Conde, G. Doria, and P. Baptista: J. Drug Del. 2012 (2012) ID 751075 .

3) M. S. Khan, G. D. Vishakante, and H. Siddaramaiah: Adv. Col. Interdace Sci. 199-200 (2013) 44.

4) Y. Niidome, A. T. Haine, and T. Niidome: Chem. Lett. 24 (2016) 488. 
5) S. Yamashita, Y. Niidome, Y. Katayama, and T. Niidome: Chem. Lett. 38 (2009) 226.

6) H. Tang, H. Kobayashi, Y. Niidome, T. Mori, Y. Katayama, and T. Niidome: J. Controlled Release 171 (2013) 178.

7) M.K. Rai, S.D. Deshmukh, and A.P. Ingle: J. Appl. Micro. 112 (2012) 841.

8) D. Manikprabhu and K. Lingappa: J. Phar. Res. 6 (2013) 255.
9) I. Chopra: J. Antimicro. Chemo. 59 (2007) 587.

10) B. Molleman and T. Hiemstra: Langmuir 31 (2015) 13361.

11) D. Aherne, D. M. Ledwith, M. Gara, and J. M. Kelly: Adv. Funct. Mater. 18 (2008) 2005.

12) C. Gao, Z. Lu, Y. Liu, Q. Zhang, M. Chi, Q. Cheng, and Y. Yin: Angew. Chem. Int. Ed.z 51 (2012) 5629. 